\title{
Income Distribution in Multinational Firms through Transfer Pricing
}

\author{
José G. Vargas-Hernández* \\ Lic. Belisario Valencia-Sepúlveda, Centro Universitario de Ciencias Económico Administrativas, Universidad de Guadalajara, \\ Zapopan, Jalisco, México \\ *Corresponding author: jvargas2006@gmail.com; jgvh0811@yahoo.com; josevargas@cucea.udg.mx
}

Received March 02, 2014; Revised March 11, 2014; Accepted March 16, 2014

\begin{abstract}
The objective of this paper is to analyze the procedures used by multinational enterprises to distribute the income generated by their subsidiaries abroad. Also, the paper intends to answer the question how multinational firms allocate taxes paid on this income among the fiscal jurisdictions in which they operate. In this study, the analytic research method was applied, by revising the available literature in order to determine how income-shifting works, as a fiscal strategy applied by MNEs. It is concluded that MNEs use organizational strategies to take advantage of the comparative advantages of the different countries in which they operate, and, as a result, an intercompany trade takes place.
\end{abstract}

Keywords: multinational firms, transfer pricing, income shifts

Cite This Article: José G. Vargas-Hernández, "Income Distribution in Multinational Firms through Transfer Pricing.” Journal of Finance and Economics, vol. 2, no. 3 (2014): 60-66. doi: 10.12691/jfe-2-3-1.

\section{Introduction}

The increase in the number of multinational firms operating in the international economy has led to a greater dynamism in the inter-firm trade. Multinational firms have the purpose to provide goods and services of equal value and quality in relation to price to consumers and costumers as the primary claimants around the world, regardless of their personal characteristics, nationality, ethnic origin, or religious creed. Intrafirm transference of prices between the different subsidiaries is determined by the flows of raw materials and commodities plus the logistics costs derived of locations. Taxation rates on foreign investments of multinational firms play a crucial role in alternative locations choices (Devereux and Griffith, 1998). Inter-firm commerce is sustained on a shared production scheme with artificially established export prices to favor transference of earnings to the home country while jobs created are subsidized by the host country economy.

That situation has forced the tax authorities of the jurisdictions in which these companies operate to implement more stringent regulations on transfer pricing in order to avoid shifting income to lower tax rate jurisdictions. About this, Robbins (2002) notes that although international businesses have been around for centuries, multinational firms are relatively a recent phenomenon. They are a natural result of the global economy. Multinational firms use their operations around the world to develop global strategies. Rather than confine themselves to their domestic borders, multinational firms search the world to find competitive advantages.
Multinational firms should be required by national and global institutions to fulfill policies regarding accountability, and, transparency, on some relevant issues such as profits, taxes, etc.

Multinational enterprises are defined as firms operating with foreign direct investment (FDI); they directly control and manage value-added activities in other countries (Peng, 2010). It is assumed that foreign investments should be highly responsive to local differences in the investment climate, institutional financial arrangements, and rates of return, taxes and other regulations and labor costs. In the last years, foreign direct investment has grown in less developed countries, attracted by tax incentives, environmental flexibility and some other advantages offered by cheap labor, etc. There are several variables considered as determinants of FDI such as macro-economic stability, labor costs, corporate taxation, corporate governance, cultural and language features, etc., variables which are considered in the context. Multinational firms can be regarded as important factors in globalization process.

Governments compete to attract multinational firms, hoping to increase tax revenues, create jobs and stimulate economic activity. In order to attract FDI, governments offer incentives to multinational firms such as tax exemptions, government support agreements, grant infrastructure, or lax environmental and labor regulations. Among the contributions that foreign-owned companies have to demonstrate are the inward flow of foreign capital and technology, tax and balance of payments contributions, spillovers on local business and communities, rate of employment rise, improvement of competitive advantages, etc. 
Other variables may be considered for location choices in international markets, such as, corporate taxation. Foreign capital restrictions are not significantly related to the taxation levels. Multinational firms are likely to deter their operations in that location where the corporation taxation is high, unless the after-tax rate of return of investments is also high (Mooij and Ederveen, 2003).

Robbins (2002) notes that managers of multinational firms face a very wide range of challenges in areas where they operate, such as, different political systems, laws, cultures, and, customs. However, these differences may originate both problems and opportunities. For example, currency devaluations of the Mexican peso lower export prices and raise import prices, and, provoke the adoption of direct protectionist formulas, which may cause some important effects on trade adjustments, and, induce FDI reshuffles.

One of the challenges facing governments and multinational firms is that about tax collection due to multinational enterprises operating in multiple tax jurisdictions that have different rules, regulations, policies and procedures. Thus, multinational corporations cannot be considered as an isolated unit but as a group of firms operating in a complex international environment. An important aspect of multinational firms is the inter-firm trade. Durán and Ventura (2003), define intercompany trade and commerce that which takes place within companies under the same organizational structure and ownership of capital, between parent and subsidiary or subsidiaries, or, between the subsidiaries and affiliates.

This situation places multinational firms in a favored position. A key reason why the intercompany trade differs from trade of full competence results from the fact that multinational business can alter their transactions to minimize their tax burden around the world. For example, firms may use transfer-pricing techniques that allow them to shift profits to jurisdictions with low tax rates and thus minimize their overall tax burden (Clausing, 2000). The price at which the parties exchange goods or services related is known as Transfer Pricing. Guidelines Applicable to Transfer Pricing and Multinational Enterprises Tax Administrations of the Organization for Economic Cooperation and Development ("OECD") states that the transfer prices are significant for both tax payers and tax administrations because that largely determine the income and deductions, and therefore the tax base of the associated companies operating in different tax jurisdictions (OECD, 1993).

More than 60 governments have adopted regulations regarding transfer pricing. Regulation of transfer prices are based on full competence principle known as "arm's length principle", (Wikipedia2012). This means that the transfer prices of goods and services on intercompany transactions must be based on an analysis of prices agreed in comparable transactions between two or more unrelated parties in a fully competitive market. In the case of Mexico, the institution responsible for compliance with these regulations is the Tax Administration Service (Servico de Administración Tributaria, SAT), the rules and regulation applicable to transfer pricing are described in Articles, 86, paragraphs XII, XIII and, 215, 216,216-bis and 217of the Law on Income Tax of Mexico (Ley del Impuesto sobre la Renta, LISR). Article 216-bis of the Income Tax Law refer to the special rules applicable to companies in the maquiladora industry. In addition, as part of the tax, report issued by the external auditor should reveal the transactions carried out with related parties abroad, and answer the questionnaires concerning the revision of taxes.

This paper analyzes the organizational strategies employed by multinational firms around the world in order to exploit the competitive advantages of host countries. In particular, the tax regulations applicable to transfer pricing to minimize their tax burden by placing income in tax jurisdictions with lower tax rates. This is in response to different tax rates observed within the member countries of OECD.

This document is divided into the introduction and four sections. The next section reviews the economic literature available in relation to the phenomena of multinational firms, international production, intercompany trade, and, relevant aspects of transfer pricing. In this same section also, all this information is put in the framework of the institutions based theory. The second section presents three types of organizational strategies that correspond to the evolution of multinational firms. These strategies give rise to intercompany trade. The third section presents a discussion of the problems faced by multinational firms and tax authorities to determine the taxable base and the application of transfer pricing methods to determine that the intercompany transactions are agreed on the principle of full competition. Finally, in the fourth section, the way in which multinational enterprises can minimize their tax burden through transfer pricing is illustrated.

This paper intends to analyze the income distribution in multinational firms through transfer pricing. To achieve this aim, first it reviews the theoretical framework of interfirm trade and transfer pricing. Second, it describes the different organizational strategies of multinational firms related to multinational firms transfer pricing and taxes and examine minimizing tax burden through transfer pricing to finally conclude that organizational strategies of multinational firms generate inter-firm trade across borders, so that multinational firms are forced to agree a transfer price to exchange goods and services.

\section{Inter-firm Trade and Transfer Pricing: A Review of the Theoretical Framework}

In order to explain the phenomenon of multinational firms is necessary to start by reviewing the classical theories of international trade, which have their origin in the Adam Smith theory, and, the absolute advantage and comparative advantage theory of David Ricardo, which were systematized by Eli Heckscher and Bertil Ohlin. The Heckscher-Ohlin model states that countries export products that use their abundant and economic factors of production and import products that use scarce factors of production in the country. During the 1970s, emerged the "new trade theory" addressing issues of trade specialization, and also the location of productive activities in different countries and regions (Helpman and Krugman, 1985).

As for research related to inter-firm trade, Durán and Ventura (2003) argue on the interest of economists associated to inter-firm trade in relation to international production, mainly to the impact of multinational firms in 
the international distribution of income, and tax issues arising from transactions between related companies. The research was focused on explaining the internationalization of production and its relationship with FDI. Among the most prominent studies are included: Vernon (1996) studied the life cycle of the product. The issue of internationalization of production is discussed by authors such as Hymer (1976), Kindleberger (1990), Caves (1971), among others. In these works the concern is for inter-firm trade that appears as a side issue.

However, the Japanese researchers, Kojima and Ozawa (1984), based on the Japanese experience, suggested that FDI would be an efficient conduit of trade in intermediate products between the companies involved and those on investment (subsidiaries) that can benefit from comparative advantages complementing the activities of their parent companies. As for the research on transfer pricing, transfer of goods, technology and services between related parties located in different countries, it is suggested that the price agreed in such transactions within the multinational firms, is set based on various conditions determined by company management (Durán and Ventura, 2003). Early studies in this line were those of Cook (1955) and Hirshleifer (1956), followed later by Horst (1971), and Itagaki (1982). These works share the concern that the transfer prices erode the tax bases of host countries.

Moreover, from the point of view of the leader strategies on strategy, institutions based vision, provides a framework within which to develop this work. It starts from the definition of institutions provided by North (1990), who defines institutions as humanly planned constraints that structure political interaction, and, economic and social development. They consist of informal institutions (sanctions, taboos, customs, traditions and codes of conduct), and formal institutions (constitutions, laws, property rights). An institutional constraint such as formal and informal rules, affects entrepreneurship, although this entrepreneurship flourishes around the world, their overall development is uneven (Peng, 2010: 130). The institutions-based vision can help to explain how taxes affect intercompany trade patterns of multinational firms and explain the fact that multinational enterprises invest in subsidiaries around the world in order to exploit the comparative advantages of different countries.

\section{Organizational Strategies Multinational Firms}

According to the United Nations Conference on Trade and Development (UNCTAD), the ability of multinational firms to contribute to international economic integration is a result of their own attributes and how they respond to the political environment and economic context in which they operate (UNCTAD, 1993). Mexican multinationals, (large and medium size businesses), operate in many different industries using their organizational and technical capabilities and competencies to develop and deliver market-based products and services that meet the needs of local consumers.

To achieve these tasks, Mexican multinationals design and implement strategies to create scale and scope economies; engaging in strategic alliances, joint ventures, partnerships, and associations with other partners, NGOs, community developers, supply and distribution chain partners; leveraging logistical networks; decreasing prices; removing and liberating market constraints, etc., (Rangan, Quelch, Herrero and Barton, 2007, UNDP, 2008). Strategies of multinational firms evolve as they respond to various pressures, challenges and opportunities, among which we can mention the advances in information and communication technologies, convergence of consumption patterns around the world, intensifying competition and opening markets, etc.

Some markets in developed and developing countries are expected to tighten in the next following years due to increased price competition and consolidation among manufacturers, leaving Mexican multinational firms to seek out new markets in other developing and emergent economies. CEMEX operated in a highly protected legal environment and no significant competition on price until the 1990s and controlled 65 percent of the market shared. Other good example is the recent success of Wal-Mart, with its proprietary distribution sites and aggressive supplier price targets, has helped alter the retail food landscape and set new competitive standards. With no value added tax on food, the efficiencies have had impact across the supply chain and have been passed on as lower prices to consumers (Goldstein, 2007).

One important lesson to be learned by multinational firms is to manage price strategies to improve their market performance in less developed economies through the scalability of innovations and by discarding traditional approaches to price-performance improvements. These new strategies involve significant changes in the way that production is organized across borders, which has led multinational firms to locate a wider range of valuegenerating activities abroad (UNCTAD, 1993).

Under the strategy of vertical expansion, the multinational firms exploits a comparative advantage in terms of production factors and prices, etc. by locating intangible assets and human resources in foreign economies, either through a backward vertical expansion to procure production and distribution of a raw materials, inputs and components, or through a forward vertical expansion by distributing and selling goods and services. Vertical foreign investment encourages multinational firms to undertake foreign production in order to give more certainty to supply and asset specificity.

Multinational corporations operating in low income market segments are consciously cost management systems oriented for innovation, organization, manufacturing, distribution, etc., to achieve a competitive price performance, capital efficiency and sustainable profits. NAFTA has resulted in reallocation effects of productive sectors based on relative prices changes, with very poor impact on the performance at firm learning level, technical inefficiencies and lack of innovation. Below, three types of organizational strategies are presented, described in the World Investment Report published by UNCTAD (1993), corresponding to the evolution of multinational firms. All these organizational strategy can result in inter-firm trade.

\section{A. Strategy of party autonomy}

This strategy consists in establishing subsidiaries operating independently in the host countries. The main link between the parent and its subsidiary abroad is by 
controlling shareholder. Other relationships may include technology transfer and provision of long-term capital. The parent company exercises little control over the subsidiary, while it is profitable. In general, an independent subsidiary is responsible for most of the generative process of production value, through which develops relationships with local suppliers and subcontractors. It also employs local workers and managers, conducts its financial transactions with local financial intermediaries, and may participate in international trade with other countries. Companies can control many natural autonomous subsidiaries, each one serving at different host country (UNCTAD, 1993). An independent subsidiary can be seen as a replica of the parent (multinational firm) in its new location.

According to UNCTAD (1993), there are three organizational strategies that the multinational firms can perform. The evolution of strategies performed by multinational firms can be schematically shown in the following diagrams (See Figure 1).

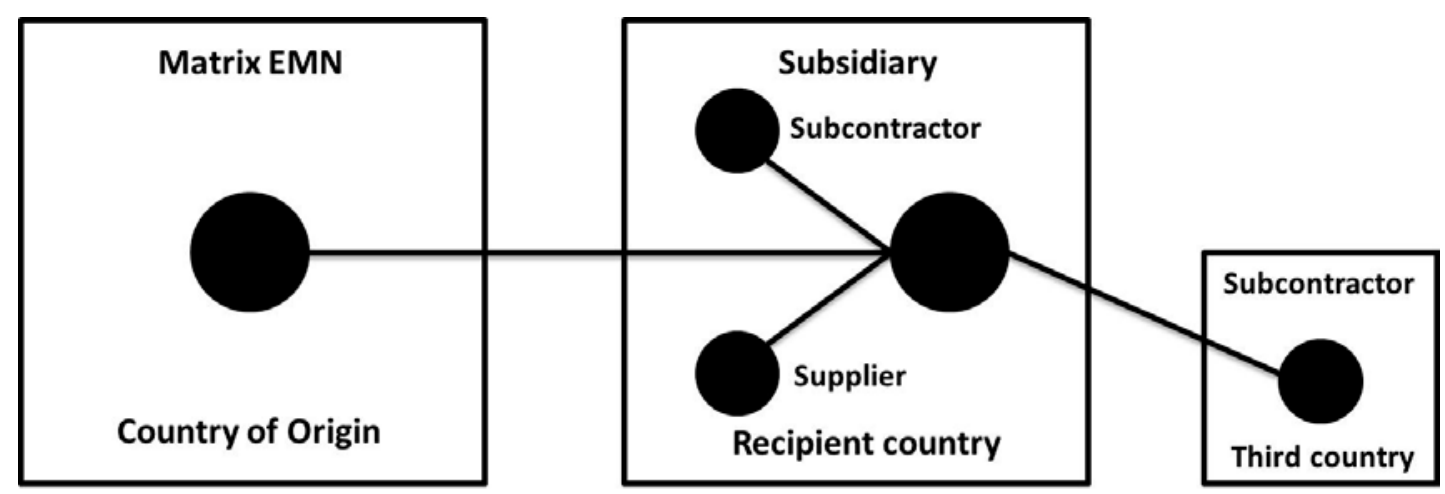

Figure 1. Strategy: autonomy of parties

Source: UNCTAD (1993). World Investment Report 1993, Transnational Corporations and Integrated International Production, New York, No. E.93.II.A.14 Graphic V.2, p. 119.

\section{B. Outsourcing strategy (Outsourcing)}

Some multinational firms participate in international production through subcontracting (outsourcing). The activities in host countries are linked to processes performed in other territories, mainly in the countries of origin of multinational firms (Figure 2). In the case of services, some multinational firms use foreign affiliates or subcontractors to process information or develop software. Services have become tradable due to technological advances in computing and communication (UNCTAD, 1993).

The international outsourcing of production represents the transfer of value generating activities in territories, other than the country of origin of multinational firm. Also this transfer of value may be different than other in end-user countries where the products are destined. The principal reason for outsourcing is to exploit the comparative advantages of host countries. Production is controlled by the multinational firms through stock controls or through contracts with local firms, which allows the multinational enterprises to concentrate in some certain parts of the value chain, while the subcontractor is specializing in the production, or other intensive labor process (UNCTAD, 1993).

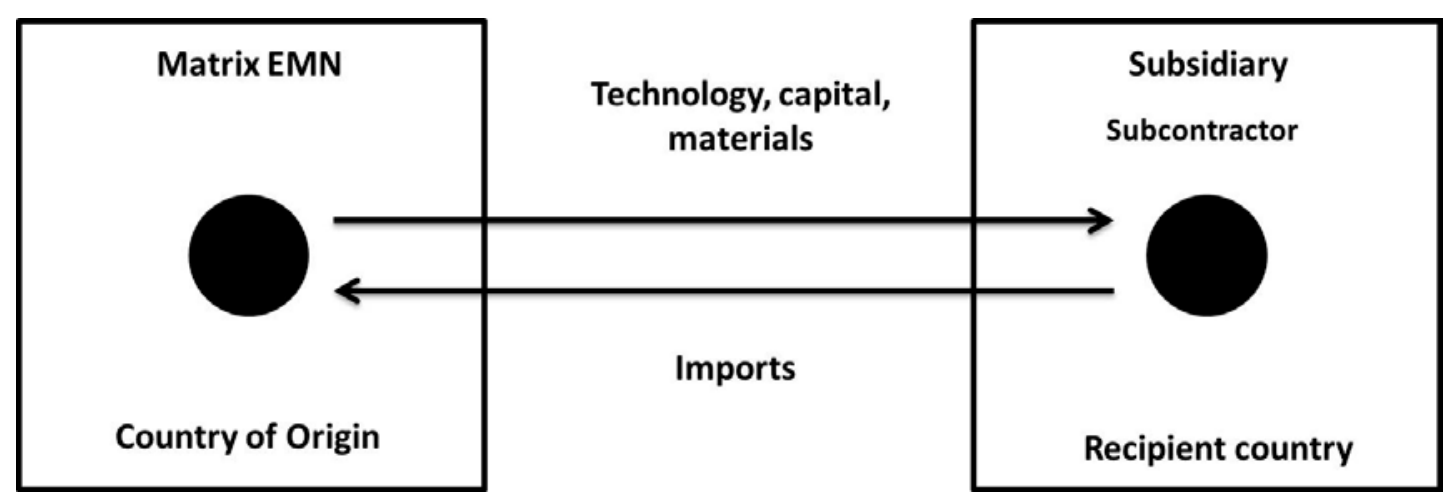

Figure 2. Strategy of subcontracting or outsourcing

Source: UNCTAD (1993), World Investment Report 1993, Transnational Corporations and Integrated International Production. New York, No. E.93.II.A.14 Graphics V.3, p. 120.

\section{Complex integration (Integrated Production Systems International)}

For some multinational firms, international production can occur almost anywhere in the value chain. The complex integration strategy is based on the firm's ability to locate their production, or supply of resources, where more profitable. Under the complex integration strategy, any subsidiary operating in any territory can perform for the whole multinational firm. Each transaction is valued in terms of its contribution to the value chain. The complex integration required to locate various functional activities not only production but also research and development, finance, accounting, etc., where they can be more successfully performed according to the strategy of the multinationals (UNCTAD, 1993). Under the complex integration model, there is an interrelationship between functions, processes and various territories in which the 
MNE operates. However, not all elements of the value chain are integrated in the same grade (Figure 3 ).

\section{Multinational Firms Transfer Pricing and Taxes}

Due to the growth of FDI and increased activities of multinational firms, a greater number of activities in the value chain of enterprises groups of companies take place in different countries. This generates complex questions about where taxable income is generated by multinationals, as this is distributed among firms located in different countries, and as distributed taxes paid on this income between tax jurisdictions (UNCTAD, 1993). To answer these questions, it is necessary to know the position of tax authorities regarding tax rates applicable to multinationals operating in two or more tax jurisdictions. The tax rates of each country will depend on whether the country uses a tax system that is based on residence, based on the origin, or both.

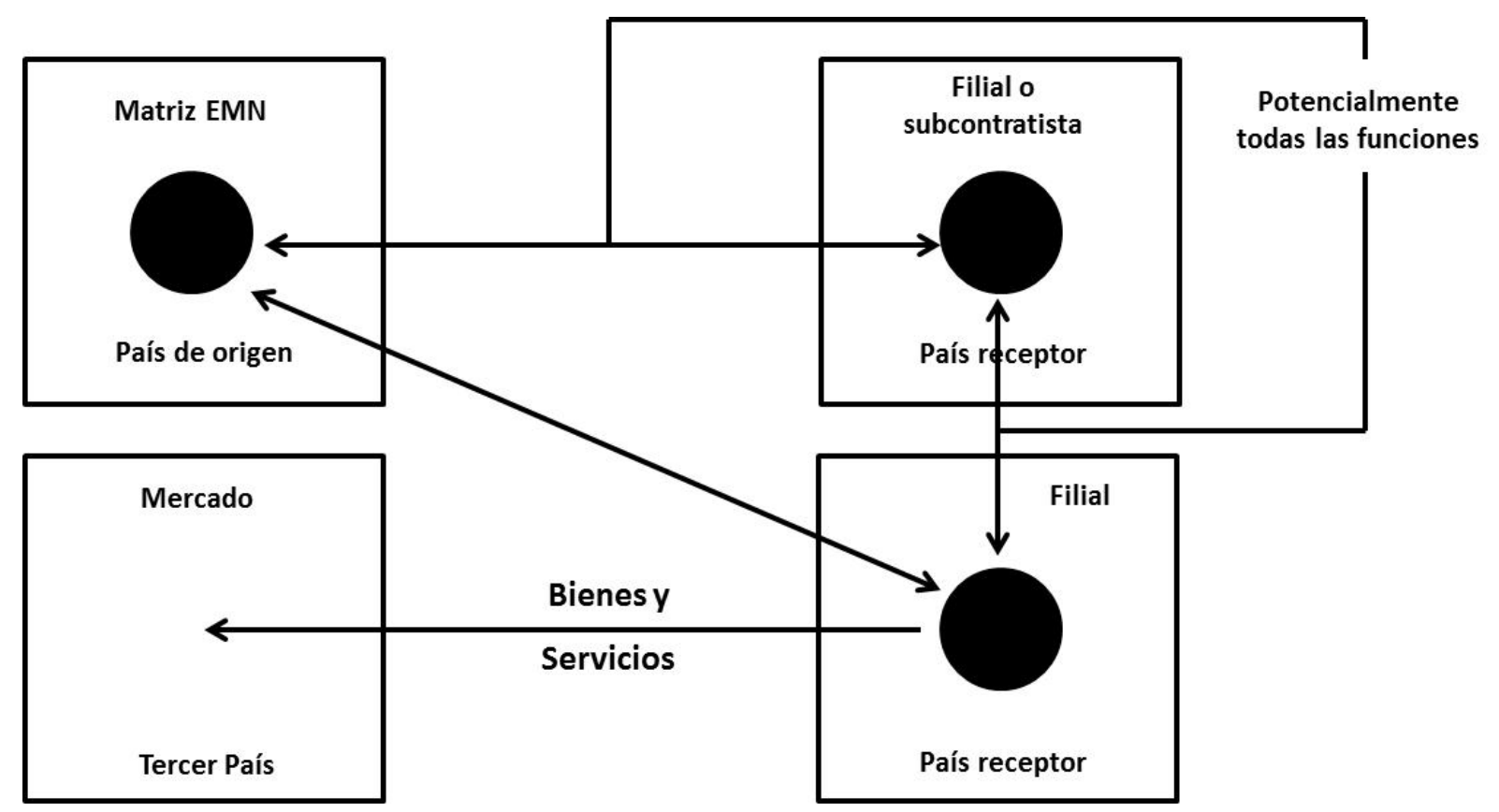

Figure 3. Strategies of complex integration

Source: UNCTAD (1993).World Investment Report 1993, Transnational Corporations and Integrated International Production, New York, No. E.93.II.A.14 Graphic V.3, p. 120.

In a tax system based on residence, a country will include in its tax base all or part of the revenue, including revenue generated outside the country, by any person or entity considered a resident in that jurisdiction. In a tax system based on the origin, a country includes in its tax base all or part of the revenue generated within their tax jurisdiction, regardless of the taxpayer's residence. Often, because these systems are applied together, it is given to treat each independent entity within the group of multinational firms. The OECD member countries have adopted this approach, of independent entities as the most reasonable to achieve equitable outcomes and to minimize risks of double taxation. Thus, each group member is subject to a tax on income derived from the country of residence, based on the origin (OECD, 1993).

To apply the approach of independent entities, when goods cross borders through the internal channels of multinational firms, it is necessary for tax purposes to agree in a transfer price. Transfer prices are the prices at which companies transfer tangible and intangible goods, or provide services to related parties (OECD, 1993). However, when tax rates differ among the jurisdictions in which they operate, the multinational firms have an incentive to agree on transfer price so as to reduce their tax burden, reporting higher profits in the country where the profits are recorded more slightly (Bernard and Weiner, 1990). The number of multinational firms that agree upon transfer prices in a way that minimizes their tax liability is restricted by the regulations of their countries of origin and host countries, and, the tax authorities' ability to enforce these regulations (Bernard and Weiner, 1990).

In the specific case of Mexico, the laws applicable to transfer pricing are found in Articles 86 paragraph XII, XIII and XV, 215, 216, 216-bis and 217 of the Income Tax Law. Article 215 of the Income Tax Law establishes the use of arm's length principle ("arm's length principle") to evaluate the transfer pricing agreed with related party abroad. Article 216 establishes the transfer pricing methods that taxpayers may use to assess compliance with arm's length principle.

Article 86, Section XV, establishes the hierarchy of transfer pricing methods in the order laid down in Article 216, starting with the traditional transactional methods:

Comparable uncontrolled price method (Método de precio comparable no controlado, "MPC"), compares the price agreed in the related party transactions to the price agreed with /or between independent parties in comparable transactions.

Resale price method (Método de precio de reventa,"MPR"), compares the gross profit obtained when an entity sells products to a party related to the gross profit obtained with / or between independent parties in comparable transactions. 
Added cost method (Método de costo adicionado, "MCA"), which is used to determine the selling price of goods, the provision of a service or compensation of any other transaction between related parties, multiplying the cost of goods, services or the operation concerned, by the result of adding to the unit the gross profit percent that would have been agreed with/ or between independent parties in comparable transactions.

On the other hand, there are transactional methods based on utilities:

Utility partition method (Método de partición de utilidades "MPU"), which is applied to allocate operating income obtained by related parties in the proportion that had been allocated to/ or between independent parties.

Residual method of utilities partition (Método residual de partición de utilidades "MRPU"), which is applied to allocate minimum operating income obtained by related parties in the proportion that had been assigned with / or between unrelated parties, and then determine the residual value of the transaction. The residual profit is allocated among the related parties involved in the operation taking into account, significant intangibles used by each, in proportion as it had been distributed with / or between independent parties in comparable transactions.

Transactional margin method of operating income (Método de márgenes transaccionales de utilidad de operación "MMTUO"), which is used to identify related party transactions, income from operations that have obtained comparable companies or independent parties in comparable transactions and operations, based on factors that take into account profitability variables such as assets, sales, costs, expenses or cash flows. These methods fulfill the application of arm's length principle set forth in the Guidelines Applicable to Transfer Pricing for Multinational Enterprises and Tax Administrations of the OECD.

\section{Minimizing Tax Burden through Transfer Pricing}

Politicians constantly worry about the difference between the tax rates of countries, particularly fear that if tax rates are too high may lose economic activity, discourage investment, which can be moved to countries with lower tax rates (Bartelsman and Beetsma, 2001). As the government needs to ensure that in designing their tax systems, maintain their tax base and provide a favorable climate for business and investment (UNCTAD, 1993). However, the difference between the tax rates not only induces shifts in the business, but also can generate countable income shifts between firms across countries. These income shifts are not prominent in the political debates. However, if politicians were concerned about the shift of income, so it's about moving countable income of industrialized economies to the so-called "tax havens" small countries with very low rates of corporate taxes (Bartelsman and Beetsma, 2001).

The empirical analysis developed by Bartelsman and Beetsma (2001), shows the import of the shift in income between industrialized economies as a result of differences in tax rates. There are two ways in which multinational firms can shift their income from countries with high tax rates to countries with lower tax rates. First, the financial structure of the subsidiaries is relevant to the taxation of multinationals. In particular, it is relatively more attractive financing to subsidiaries in countries with high tax on credit, instead of capital, with loans extended by the parent or other subsidiaries in different countries. The second channel for income shifting through borders refers to prices that are used in inters firm transactions in the international trade in goods and services (Bartelsman and Beetsma, 2001).

Many times it is difficult to put into practice the strict application of arm's length principle. For example, for many transactions inter firm there is no comparable transactions between third parties independent or not. Therefore it is difficult to apply a traditional transactional method. Thus; multinational firms can reduce their tax liabilities reporting transfer prices as low as possible. The shift of income leads to differences between reported income and the "true" income generated in the business. The usefulness of the reported production is reduced or increased in countries with relatively high or low taxes, because the companies agree lower or higher prices than the market in their inter firm transactions (Bartelsman and Beetsma, 2001).

\section{Conclusion}

Multinationals are firms that operate with FDI, generating value-added activities in different territories. Multinationals make the decision to locate in certain countries because it has the opportunity to exploit comparative advantages of these countries, so it is no longer possible to consider the multinational firms as an isolated unit but rather as a group of firms operating in a global context.

Organizational strategies of multinational firms generate inter-firm trade across borders, so that multinational firms are forced to agree a transfer price to exchange goods and services. This has created challenges and opportunities for governments and multinational corporations, especially in fiscal matters. For this reason the tax authorities of more than 60 countries have adopted regulations regarding transfer pricing, which are based on the principle of full competition, and the traditional transaction methods and based on earnings embodied in the Guidelines Applicable to Mater of Transfer Pricing for Multinational Enterprises and Tax Administrations of the OECD.

However, due to the existence of different tax rates between different jurisdictions in which a multinational firm may operate, there is an incentive for these agreed upon transfer prices as low as possible, and thereby it displaces the extra revenue to the jurisdictions with a lower tax rate. For this reason it is necessary that the tax authorities apply more efficient regulations on transfer pricing to avoid the tax bases of governments to be eroded by such strategies put into practice by multinational firms.

Intergovernmental agreements between the involved nation-states to regulate operations and activities of multinational firms should emerge to have cross-national policies to control on issues such as accounting guidelines and procedures, investments, financial accountability, tax and profits, transfer of prices and social corporate responsibility. 


\section{References}

[1] BERNARD, J. T. Y WEINER R. J. (1990). Multinational Corporations, Transfer Prices, and Taxes: Evidence from the U.S. Petroleum Industry, Taxation in the Global Economy, The University of Chicago Press, Chicago, 123-154.

[2] BARTELSMAN, E.J. Y BEETSMA R.M. (2001). "Why Pay More? Corporate Tax Avoidance through Transfer Pricing in OECD countries”. Journal of Public Economics 87, 2225- 2252.

[3] CAVES, R. (1971)."International corporations: The Industrial Economics of Foreign Investment", Economica, Vol 38, febrero, $1-27$.

[4] CLAUSING, K. A. (2000). "The Impact of Transfer Pricing on Intra Firm Trade.” In Hines, J. R. International Taxation and Multinational Activity, University of Chicago Press, Páginas 173200.

[5] COOK, P. (1955). "Decentralization and Transfer Pricing Problem”. Journal of Business, 28, 87-94.

[6] DEVEREUX, M.P. AND R. GRIFFITH, (1998), Taxes and the Location of production: evidence from a panel of US multinationals, Journal of Public Economics 68: 335-367.

[7] DURÁN, J. E. Y VENTURA, V. (2003).Comercio intra-firma: concepto, alcance y magnitud, CEPAL, División de Comercio Internacional e Integración, diciembre.

[8] GOLDSTEIN, A (2007) Multinational companies from emerging economies. Palgrave McMillan: New York.

[9] HELPMAN, E. Y KRUGMAN P. (1985). Market Structure and Foreign Trade. Cambridge. MIT Press.

[10] HIRSHLEIFER, J. (1956). "On the Economics of Transfer Pricing", Journal of Business, 29, 172-189.

[11] HORST, T. (1971)."The theory of the multinational firm: Optimal behavior under different tariff and tax rates", Journal of Political Economy 79, 1059-1072.

[12] HYMER, S. H. (1976). The International Operations of National Firms: A Study of Direct Foreign Investment. Cambridge. MIT Press.
[13] ITAGAKI, T. (1982). "Systems of Taxation of Multinational Finns under Exchange Risk," Southern Economic Journal vol. 48, 437-448.

[14] KINDLEBERGER, C. (1990). The International Corporation. The MIT Press, Cambridge, Massachusetts.

[15] KOJIMA, K, Y OZAWA, T. (1984), "Micro and Macro Economic Models of Foreign Direct Investment: Towards a Synthesis". Hitotsubashi Journal of Economics, 25: 2:1-20.

[16] MOOIJ, R.A. DE, AND S. EDERVEEN, (2003).Taxation and Foreign Direct Investment: a Synthesis of Empirical Research, International Tax and Public Finance 10, 673-693.

[17] NORTH, D. (1990). Institutions, Institutional Change, and Economic Performance (Chapter 1: An introduction to institutions and institutional change). Cambridge University Press, New York, 3-10.

[18] OCDE (Organización de Cooperación y Desarrollo Económico) (1993), Transfer Pricing Guidelines for Multinational Enterprises and Tax Administrations, OCDE Letter, Paris.

[19] PENG, M. (2010).Estrategia Global, 2da. Ed., México, Cenage Learing.

[20] RANGAN, V. K., J. QUELCH, G. HERRERO AND B. BARTON (2007). Business Solutions for the Global Poor. Jossey-Bass, San Francisco.

[21] ROBBINS, S. P. (2002). Comportamiento Organizacional, 7a. Edición, México, Pearson.

[22] SAT (Sistema de Administración Tributaria), Ley del Impuesto sobre la Renta, México.

[23] UNCTAD (Conferencia de las Naciones Unidas sobre el Comercio y el Desarrollo) (1993). World Investment Report: Transnational Corporations and Integrated International Production. Naciones Unidas, New York.

[24] UNDP. (2008). Creating Value for All: Strategies for Doing Business with the Poor, United Nations Development Program.

[25] VERNON, R. (1966)."International investment and international trade in the product cycle", Quarterly Journal of Economics, Vol. 80, mayo, $190-20$. 